\title{
Rola informacji z perspektywy dynamicznej interpretacji „trudnej przyjaźni” Polski i Ukrainy
}

$\mathrm{D}^{\circ}$ owolny obiekt materialny lub system, w którym występują relacje materialne (np. człowiek, społeczeństwo), można opisać za pomocą trzech czterech czynników: energii, którą przetwarza albo może przetwarzać, bądź która jest w nim nagromadzona; materii, $\mathrm{z}$ której jest utworzony; struktury, która jest rozmieszczeniem energii i materii w czasoprzestrzeni, ich zorganizowaniem wyrażanym w ustanowionym prawie i jego stosowaniu - ustroju oraz kultury, która określa kierunek zmian w tym rozmieszczeniu determinując cel zmian w czasoprzestrzeni ${ }^{221}$.

Organizm ludzki realizuje funkcje systemu autonomicznego. Zachodzi oddziaływanie na otoczenie - układ złożony (complex system), pobieranie informacji i energii z otoczenia, przetwarzanie ich i przechowywanie oraz utrzymywanie się w równowadze funkcjonalnej (homeostazie). Dlatego też można rozpatrywać społeczeństwo jako nadsystem autonomiczny skonstruowany z ludzi jako jego podsystemów autonomicznych.

Społeczeństwo zorganizowane $\mathrm{w}$ państwo może być rozpatrywane jako system cybernetyczny, ponieważ posiada oczywiście wyróżnioną substancję składającą się z materiału i energii (przyczyny: sprawcza i budulcowa), określoną strukturę (przyczyna formalna) $^{222}$ i realizowany cel (przyczyna celowa). Za materiał, z którego ukształtowany jest ten system, należy traktować ludzi. Zaś liczebność danego społeczeństwa daje wyraz ilości materiału, który można określać pojęciem masy socjologicznej lub socjomasy. Za wskaźnik energii nagromadzonej w systemie, którego przykładem jest społeczeństwo, można uznać pracę użyteczną i aktywność ekonomiczną, którą dane społeczeństwo może wykonać lub wykonuje. Inaczej mówiąc, jest to zdolność robocza lub zdolność wykonawcza społeczeństwa służąca do jego przetrwania, więcej do zachowania zdolności w podejmowaniu jakichkolwiek

\footnotetext{
${ }^{221}$ J. Kossecki, Cybernetyka społeczna, Warszawa 1981, s. 15, 31-32.

${ }^{222}$ J. Świniarski, O naturze bezpieczeństwa, Warszawa-Pruszków 1997, s. 225-227.
} 
innych zajęć i aktywności ${ }^{223}$. Dodatkowo wielkość pracy wykonywanej przez społeczeństwo można precyzyjnie mierzyć, np. wielkość produkcji, liczba i charakter usług wykonywanych przez społeczeństwo, operatywności i możliwości technologiczne toru informacyjnego. Zdolność robocza oraz energia przetwarzana przez społeczeństwo składają się w sumie na energię socjologiczną ${ }^{224}$. Natomiast struktura państwa jako systemu społecznego, to wzajemne czasoprzestrzenne relacje elementów systemu tzn. ludzi, ich zorganizowanie na podstawie określonego prawa i ich zdolności jego rozumienia i stosowania. Z punktu widzenia procesów sterowniczych w socjostrukturze, najważniejsze znaczenie ma sprzężenie zwrotne między kierownictwem i wykonawcami, czyli układami złożonymi poddającymi się opisowi na różnych poziomach funkcjonalnych. Dynamika związku między tymi układami bierze się z procesów zachodzących w każdym z ich i wzajemnego oddziaływania między nimi.

\section{Filary bezpieczeństwa systemu społecznego}

Niewątpliwie wolność, równość i braterstwo lub solidarność oraz odpowiedzialność ludzi spełniających swe życie w dobrostanie - poczucie bezpieczeństwa politycznego, społecznego, ekonomicznego, kulturowego to ogólny cel pozostający w związku i współzależności z współtowarzyszącymi bezpieczeństwo filarami i podsystemami ujętymi holistycznie. Jest to współzależność z udziałem takich wyznaczników ${ }^{225}$ : „prokreacja i edukacja” (relacje ilościowo-jakościowe „masy” i socjomasy), „dostatek i dobrobyt” implikowanymi potencjałem „energii” i socjoenergii (pozyskiwanej autonomiczne lub w kooperacji); ,prawo i ustrój strukturalizujący dany system społeczny” (jakościowa pochodna „przestrzeni i socjostruktury”) oraz „wartości preferowane w danym systemie”, np.: wolność, równość, praworządność, braterstwo, solidarność, odpowiedzialność (jakościowa pochodna „czasu” i socjokultury).

Przez bezpieczeństwo w ujęciu filozoficznym, z perspektywy wymienionych czterech filarów, można pojmować jego przybliżoną, przestrzenną formę ustrukturalizowanego istnienia z takimi atrybutami, jak: (1) trwanie, (2) przetrwanie i rozwój oraz (3) doskonalenie - odnajdujące się w ,prokreacji, edukacji i informacji”, „dostatku i dobrobycie” oraz (4) „wspólne dobro, praworządność i określone wartości preferowane, np. w

\footnotetext{
${ }^{223}$ Interesujące stanowisko w tej kwestii zawarte jest w pracy brytyjskiego antropologa kultury Dawida Graebera Praca bez sensu. Teoria, thum. M. Denderski, Wydawnictwo Krytyki Politycznej, Warszawa 2019.

${ }^{224}$ J. Kossecki, Cybernetyka społeczna, op.cit.., s. 31-32.

${ }^{225}$ J. Świniarski, Źródta realistycznej i idealistycznej tradycji refleksji o bezpieczeństwie narodowym, „Studia Bezpieczeństwa Narodowego" 2011, nr 7, s. 65.
} 
modelu liberalnej demokracji czy „niedokończonym projekcie oświeceniowym”: Wolność, Równość, Braterstwo i Solidarność, Odpowiedzialność ${ }^{226}$. Konkludując i syntetyzując powyższy wywód można go przedstawić w poniższej tabeli.

Tabela 1. Warunki początkowe wszechświata, pierwsze przyczyny Arystotelesa i podstawowe elementy systemu społecznego oraz filary holistycznie pojętego bezpieczeństwa

\begin{tabular}{|c|l|c|l|}
\hline $\begin{array}{c}\text { Warunki } \\
\text { początkowe } \\
\text { wszechświata } \\
\text { wg TWW }\end{array}$ & $\begin{array}{c}\text { Pierwsze } \\
\text { przyczyny } \\
\text { wg Arystotelesa }\end{array}$ & $\begin{array}{c}\text { Elementy systemu } \\
\text { społecznego } \\
\text { wg cybernetyki społecznej }\end{array}$ & $\begin{array}{c}\text { Filary holistycznie } \\
\text { bezpieczeństwa } \\
\text { liberalnej demokracji }\end{array}$ \\
\hline Czas & Celowa & $\begin{array}{c}\text { Socjokultura } \\
\text { (preferowany system wartości) }\end{array}$ & $\begin{array}{c}\text { wolność, równość i braterstwo, } \\
\text { odpowiedzialność }\end{array}$ \\
\hline Energia & Sprawcza & $\begin{array}{c}\text { Socjoenergia } \\
\text { (wyrażana w miarach } \\
\text { ekonomicznych) }\end{array}$ & Dostatek i dobrobyt \\
\hline Przestrzeń & Formalna & $\begin{array}{c}\text { Socjostruktura } \\
\text { (zorganizowanie systemu } \\
\text { społecznego, jego rodzaj) }\end{array}$ & Prawo i ustrój (prawodawstwo) \\
\hline Masa (materia) & Budulcowa & $\begin{array}{c}\text { Socjomasa } \\
\text { (ilość } \text { i jakoś ludzi) }\end{array}$ & Prokreacja i edukacja \\
\hline
\end{tabular}

Opracowanie własne na podstawie: J. Świniarski, Wł. Chojnacki, Filozofia bezpieczeństwa. Podręcznik Akademicki, Warszawa 2004; J. Świniarski, P. Kawalerski, Drogi i bezdroża securitologii, Warszawa 2019, rys. 44, s. 187.

W zaprezentowanym ujęciu tabelarycznym bezpieczeństwo w wąskim pojmowaniu sprowadza się do twardego rdzenia identyfikowania go z czasoprzestrzenią ${ }^{227}$ oraz ze stanem socjostrukturalnym systemu społecznego. Przyjmując takie stanowisko bezpieczeństwo determinuje przestrzeń i socjostruktura zawierająca się $\mathrm{w}$ prawie, ustroju, sposobu zorganizowania życia społecznego oraz zdolności postrzegania i przestrzegania zasad jego funkcjonowania. Tę pierwszą z wymienionych identyfikacji (z przestrzenią) eksponuje m.in. wyrosła $\mathrm{z}$ obszaru nauk przyrodniczych, technicznych i teorii niezawodności systemów oraz urządzeń technicznych teoria interdyscyplinarna - teoria bezpieczeństwa systemów ${ }^{228}$. W teorii tej bezpieczeństwo jest pojęciem wieloaspektowym ${ }^{229}$, zarówno subiektywnym, jak i zależnym od czasoprzestrzeni (miejsca i momentu czasu). Niemniej na jej gruncie przyjmuje się, że dobrze jest identyfikować bezpieczeństwo z właściwością zarówno czasoprzestrzeni, jak i zdolnością systemu w niej zakotwiczonego do niezawodnego wykonywania zadanych funkcji, co oznacza

\footnotetext{
${ }^{226}$ Znane stanowisko Immanuela Kanta - Oświecenie to wyjście człowieka z niedojrzałości. To jest idea, która mówi, że człowiek może świadomie kierować swoim życiem w sposób racjonalny, zgodnie ze wskazaniami rozumu.

${ }^{227}$ J. Jaźwiński i K. Ważyńska-Fiok, Bezpieczeństwo systemów, Warszawa 1993.

${ }^{228}$ Ibidem, s. 13.

${ }^{229}$ Ibidem, s. 11.
} 
także, do bezpiecznego ich zrealizowania ${ }^{230}$. A zatem bezpieczeństwo jest atrybutem (1) czasoprzestrzeni - nieodłączną cechą czasoprzestrzeni przyrodniczej, społecznej i kulturowej; (2) zależy od dopasowania tego systemu do jakiegoś rodzaju przestrzeni, czasu i zadań oraz (3) kontroli i działania człowieka - nazywanego w literaturze przedmiotu „operatorem”. Można przyjąć, że bezpieczeństwo to złożony układ otwarty obejmujący triadę”: „,przestrzeń (czasoprzestrzeń) - system - operator (człowiek).

Rozwinięcia tej triady dokonuje się m.in. na gruncie cybernetyki społecznej, eksponując zwłaszcza rolę socjostruktury. W uproszczeniu, odnosząc tę rolę do jakościowego sposobu zorganizowania systemu społecznego w państwie, można wyróżnić trzy układy: scentralizowany, zdecentralizowany i mieszany. Takie wskazanie miar ilościowych wydaje się jednakże problematyczne. W ich identyfikowaniu zasadnym jest odniesienie się do klasycznego myślenia o państwie według Arystotelesa, wyróżniającego jego typy z uwagi na ilość ośrodków sprawujących władzę: jeden, kilka, wiele, całe spektrum uprawnionych uczestników w politei, będącej swoistym mikstem arystokracji i demokracji ${ }^{231}$. Równie ważne jest stanowisko Jeana Jacquesa Rousseau optującego za powierzaniem władzy zwierzchniej na podstawie stosunku obywateli do stanu urzędniczego ${ }^{232}$, czy modele ustrojowe Michela Foucaulta, wskazującego na peregrynację sposobów zorganizowania społeczeństw (pojawienie się rozumu urządzającego wiąało się z pewnym nowym sposobem myślenia, rozumowania, planowania nazywanym polity $\mathrm{kq}^{233}$ ), od epoki w której obowiązywało jedno prawo przez dwa prawa do epoki rozmycia się wielu praw, czyli epoki bezpieczeństwa (państwo oznacza zatem zasadę porzadkująca to, co jest, ale także coś, co być powinno $\left.{ }^{234}\right)^{235}$.

Ewaluacja procesu sterowania socjostruktury w Polsce w latach 1989-2017

\footnotetext{
${ }^{230}$ Teoria bezpieczeństwa od teorii niezawodności różni się większą elastycznością tej pierwszej. O ile teoria niezawodności kładzie nacisk na zagadnienie uszkodzeń urządzeń technicznych i przewidywalności błędów $\mathrm{w}$ ich eksploatacji przez operatorów, to teoria bezpieczeństwa eksponuje przeciwdziałanie sytuacjom zawodności tych urządzeń przez likwidację lub odparowanie zagrożeń w ich funkcjonowaniu, jeżeli ewentualnie występują. Inaczej, teoria niezawodności właściwie ignoruje znaczenie czynnika subiektywnego - działań ludzkich - zaś teoria bezpieczeństwa te działania uwzględnia. J. Jaźwiński, K. Waryńska-Fiok, Bezpieczeństwo systemów, op. cit., s. 13-18.

231 J. Świniarski, Główne koncepcje filozoficzne o realizacji bezpieczeństwa przez ustroje polityczne, [w:] Współczesne bezpieczeństwo polityczne, Stanisław Jaczyński, Mariusz Kubiak, Mirosław Minkin (red.), Warszawa-Siedlce 2012, s. $277-290$.

${ }^{232}$ J. Świniarski, O niektórych rozwinięciach projektu Immanuela Kanta o ustanowieniu wiecznego pokoju, wyjścia z cywilizacji zabijania $i$ wojny zbrojnej, [w:] Społeczeństwo a wojna. Wojna i pokój - retrospekcja $i$ współczesność, Marek Bodziana (red.), Wrocław 2014, s. $30-62$.

${ }^{233}$ M. Foucault, Bezpieczeństwo - terytorium - populacja, Warszawa 2010, s. 288.

${ }^{234}$ Ibidem, s. 289.

${ }^{235}$ J. Świniarski, Edukacja dla bezpieczeństwa w perspektywie biopolityki, [w:] Bezpieczeństwo i edukacja dla bezpieczeństwa w zmieniającej się przestrzeni społecznej i kulturowej, Ryszard Rosa (red.), Siedlce 2012, s. 319 $-343$.
} 
Stosunek obywateli państwa polskiego do zmian ustrojowych po 1989 r. wskazuje na obecność socjostruktury o charakterze mieszanym, charakterystycznej dla demokracji obieralnej, co ma m.in. także wpływ na jakość toru informacyjnego. Odtąd w systemie sterowania społecznego zaczynają silnie nakładać na siebie bodźce polityczne i ekonomiczne zamiast demograficznych, z tym utrzymana została rola norm i bodźców prawnych. Transformacja umożliwiła zmianę struktury własnościowej w gospodarce, wyłonił się nowy rynek mediów, edukacji i dóbr kulturalnych. Równocześnie umacniała się rola biurokracji w systemie sterowania społecznego. Rosnąca rola biurokracji w dużym stopniu utrudniała rozwój gospodarki wolnorynkowej, przyczyniając się także do konfliktów na podłożu zróżnicowanej motywacji, artykułowanej przez poszczególne grupy społeczno-zawodowe.

$\mathrm{Na}$ przebieg procesu transformacji ustrojowej w Polsce miała wpływ obecność trwającego od 1988 r. wchodzenia w okres zdolności zawodowych roczników wyżu demograficznego mającego miejsce $\mathrm{w}$ latach 60 . Tym samym pojawiły się nowe warunki do wykorzystywania dynamicznego i ekstensywnego systemu sterowania. Wybór przez ówczesne władze państwowe sposobu intensyfikacji rozwoju, głownie z udziałem dominacji norm i bodźców ekonomicznych, spotykały się z niezadowoleniem społecznym, kontestującym radykalną praktykę modelu ultraliberalnego rozwoju społecznogospodarczego. Skutkiem tej praktyki była rosnąca stopa bezrobocia, w 1994 r. - 2,72 mln, 1995 r. - 2,83 mln., a w 2003 r. - 3,18 mln ludzi. Po koniec lat 90. poziom życia ponad $3 \mathrm{mln}$ Polaków oscylował w granicach tzw. minimum egzystencji, a 18,1 mln osób dotykała codzienność związana z tzw. ubóstwem subiektywnym ${ }^{236}$. Postępujący od połowy 1990 r. spadek produktu krajowego brutto był efektem regresywnego systemu sterowania społecznego, charakterystycznego w dużym stopniu dla wojen informacyjnych i ekonomicznych. Regresywność taka charakteryzuje się uszczupleniem dostatku i dobrobytu - socjoenergii państwa. W latach 1994-1996 usiłowano korygować system sterowania, wpływ podejmowanych działań zwłaszcza na stopę wzrostu był mniejszy od oczekiwań. Widoczne ożywienie gospodarcze nastąpiło dopiero w pierwszych latach XXI stulecia, zwłaszcza po wejściu Polski do Unii Europejskiej.

${ }^{236}$ Ibidem, s. 301 
Tabela 2. Stopa wzrostu liczby pracujących i produktu krajowego brutto w latach 2004-2017

\begin{tabular}{|c|c|c|}
\hline Lata & $\begin{array}{c}\text { Wzrost zatrudnienia } \\
\text { w gospodarce } \\
\text { narodowej (\%) }\end{array}$ & $\begin{array}{c}\text { Wzrost produktu } \\
\text { krajowego brutto } \\
\text { (\%) }\end{array}$ \\
\hline 2004 & $-1,27$ & 5,3 \\
\hline 2005 & 0,63 & 3,6 \\
\hline 2006 & 1,34 & 6,1 \\
\hline 2007 & 2,55 & 6,8 \\
\hline 2008 & 4,17 & 5,1 \\
\hline 2009 & 1,93 & 1,6 \\
\hline 2010 & $-1,82$ & 3,7 \\
\hline 2011 & 2,36 & 4,8 \\
\hline 2012 & 0,89 & 1,8 \\
\hline 2013 & $-0,43$ & 1,7 \\
\hline 2014 & 0,51 & 3,8 \\
\hline 2015 & 2,24 & 4,6 \\
\hline 2016 & 1,83 & 3,3 \\
\hline 2017 & 3,13 & 4,6 \\
\hline
\end{tabular}

Źródto: Rachunki narodowe według sektorów i podsektorów instytucjonalnych w latach 2004-2017, GUS, Rocznik statystyczny pracy 2004-2017, GUS.

Nie bez znaczenia dla dynamicznego intensywnego systemu sterowania posiada struktura demograficzna. W Polsce po 2010 roku odbywa się wkraczanie w wiek emerytalny roczników wyżu demograficznego z lat 40. i 50. związane ze wzrostem urodzeń po II wojnie światowej. Jednocześnie $\mathrm{w}$ wiek produkcyjny zaczęły wchodzić roczniki niżu demograficznego. Wskazane warunki zakłócają funkcjonowanie intensywnego systemu sterowania społecznego z udziałem czynnika demograficznego. Organizatorzy systemu społecznego Polski nie wykorzystali możliwości jakie pojawiły się w Europie Zachodniej na początku 2015 r. w postaci zasilania systemu socjomasy czynnikiem migracyjnym ${ }^{237}$. Ze względów ideologicznych wykluczono mechanizm mogący wpływać na utrzymanie równowagi ekstensywnego systemu sterowania z jednoczesnym zapewnieniem wzrostu PKB. Zawężenie metod sterowania społeczeństwem jest wygodne dla władzy pod względem polityki informacyjnej kształtującej zachowania odpowiadające celom zarządzania chaosem, m.in. umożliwiając etykietowanie obcego/innego zagrażającego interesom narodowym. Zarządzanie chaosem pozostając wygodne dla pozyskiwania aprobaty zachowań szerokich mas wobec winnych działających na szkodę większości, domagającej się przywrócenia zapomnianych tradycji, zerwania $\mathrm{z}$,pedagogiką wstydu” $\mathrm{w}$ polityce historycznej. $\mathrm{W}$ praktyce oznaczało to korektę toru informacyjnego zarządzanego przez agendy rządowe,

${ }^{237}$ Zob.: https://www.michalstopka.pl/rynek-pracy-w-polsce-w-2019-roku/ (26.10.2020). 
odpowiedzialne za programowanie, przetwarzanie i przekazywanie informacji w ramach kreowanego toru informacyjnego. Działaniom tym towarzyszy synergia narzędzi sterowniczych ekipy rządzącej, skupionych w wyspecjalizowanych państwowych jednostkach organizacyjnych odpowiedzialnych za realizację zadań: bezpieczeństwa zewnętrznego i porządku publicznego, nauki i edukacji, kultury i dziedzictwa narodowego, mediów z polityką specjalnego doboru kadr i systemu gratyfikacyjnego.

Należy podkreślić, że ważnym elementem socjostruktury po transformacji ustrojowej stał się potencjał osobowy administracji, w tym jej zdolności opiniotwórcze wykorzystywane przez tor informacyjny. W latach 1989-2017 w Polsce nastąpił przyrost tego potencjału o prawie $265 \%$, w tym w administracji państwowej - 418\% i administracji samorządowej $210 \%$.

Tabela 3. Liczba urzędników w wybranych latach w Polsce ( $w$ tys.)

\begin{tabular}{|r|r|r|r|}
\hline \multicolumn{1}{|c|}{ Lata } & \multicolumn{1}{|c|}{$\begin{array}{c}\text { Administracja } \\
\text { państwowa }\end{array}$} & $\begin{array}{c}\text { Administracja } \\
\text { samorządowa }\end{array}$ & Ogółem \\
\hline 1990 & 42525 & 118645 & 161579 \\
\hline 2000 & 135865 & 178765 & 315336 \\
\hline 2017 & 171311 & 256361 & 428636 \\
\hline
\end{tabular}

Źródto: Rocznik statystyczny RP 1990-2018, GUS, Warszawa 1990-2018.

$\mathrm{Z}$ bezprecedensową rozbudową aparatu biurokratycznego wiążą się także inne zagadnienia, zakłócające sprawność funkcjonalną życia publicznego, m.in. nadmiarowość wydawanych w latach 2015-2019 aktów prawnych (w tym wzrost ich objętości o 21 razy w porównaniu do 1991 r.) regulujących działy życia politycznego, społecznego, gospodarczego, kulturalnego w Polsce. Jednocześnie należy również zwrócić uwagę na trendy w zwiększaniu potencjału osobowego, odnotowanego w danych statystycznych GUS-u sekcja: „Administracja publiczna i obrona narodowa; obowiązkowe zabezpieczenia społeczne” (wcześniej „Administracja publiczna i obrona narodowa; obowiązkowe ubezpieczenia społeczne i zdrowotne").

Tabela 4. Zatrudnienie w sekcji „Administracja publiczna i obrona narodowa; obowiązkowe zabezpieczenia społeczne" ( $w$ tys.)

\begin{tabular}{|l|l|l|l|l|l|l|l|l|}
\hline & 1990 & 1995 & 2000 & 2005 & 2010 & 2015 & 2016 & 2017 \\
\hline $\begin{array}{l}\text { Zatrudnienie } \\
\text { w administracji } \\
\text { wg sekcji i } \\
\text { działów [w tys.] }\end{array}$ & $\mathrm{b} / \mathrm{d}$ & 381,0 & 490,5 & 871,4 & 970,1 & 970,8 & 977,0 & 978,4 \\
\hline
\end{tabular}

Źródło: Rocznik Statystyczny GUS 1991-2017, GUS, Warszawa 1991-2017. 
Z przedstawionych danych wynika, że trendy wpływające na rozbudowę potencjałów osobowych szerokorozumianej biurokracji państwowej związane są z mnożeniem agend szerokorozumianej securitologii, a także menedżeringu, finansów i reklamy - w kontrze do redukowania miejsc pracy $\mathrm{w}$ przemyśle, służbie zdrowia, edukacji i placówkach opiekuńczych. Od 2019 r. na jakość socjostruktury zaczyna wpływać nowa fala wymiany pokoleniowej zasilającej potencjał produkcyjny i zarazem preferowane przez nią trendy kształtowania nowej normalności o cechach progresywno-kulturowych przyjmowanych przez pokolenia „Y” (urodzeni w latach 1980-2004) i „Z” (urodzeni po roku 2004). Można zaryzykować twierdzenie, że wymienione pokolenia wykorzystując możliwości information is power (nowa jakość wobec klasycznej tezy Bacona: scientia est potentia), przyspieszą proces formowania nowej socjostruktury z udziałem zjawisk emergencji i akomodacji służących wyłanianiu się nieznanych cech złożonych układów, co do których nie sposób zdefiniować ich całościowej genezy względem hipotetycznej całości. Oznaczać to może konieczność przyspieszenia rewizji starego modelu odnajdywanego w historycznych doświadczeniach, dowodzącego że gwałtowane wstrząsy społeczne są efektem głównie strachu przed zniewoleniem socjalnym, bankructwem państwa czy skutkami śmiertelnej pandemii. Skala i charakter gniewu i determinacja masowej mobilizacji prowadzącej do gwałtownych wydarzeń publicznych może mieć także podłoże negacji narzucania norm i form toru informacyjnego, połączonego $\mathrm{z}$ pokoleniowym sprzeciwem wobec osuwania się $\mathrm{w}$,niedobrowolny dewzrost”, powodując coraz większe trudności u młodych ludzi $\mathrm{z}$ aprobowaniem dotychczasowych ram instytucjonalnych cywilizacji.

\section{Meandry roli informacji z perspektywy dynamicznej interpretacji „trudnej przyjaźni” Polski i Ukrainy}

Wszelkie formy komunikacji przewidują istnienie pewnej ilości informacji znanych obu stronom jeszcze przed rozpoczęciem interakcji jak również pola negocjowanych porozumień. Taką wspólną wiedzę stanowi język, kody identyfikacyjne i interpretacyjne używane na zasadzie suwerenności stron, wspólne odniesienia historyczne, geograficzne i kulturowe, jak również zewnętrzny kontekst sytuacyjny, w którym ma przebiegać i/lub przebiega wymiana informacji. Wyróżnione składowe determinują wzajemne zrozumienie, bez którego nie sposób zapewnić jakości obranego, spójnego toru informacyjnego. A zatem jego integralnym elementem jest określenie „współdzielonej rzeczywistości” (shared reality) umożliwiającej przyjęcie modelu skoordynowanych działań zapewniających dopasowanie przyjętego konsensu do oczekiwań. 
Zagadnienie „współdzielonej rzeczywistości” jest szczególną właściwością toru informacyjnego służącego interpretacji ,trudnej przyjaźni” Polski i Ukrainy. W latach 19902020 poddawany on był rozlicznym zabiegom korekcyjnym o charakterze programowym i realizacyjnym. Punktem wyjścia była deklaracja polityczna Polski, pierwszego państwa uznającego suwerenność i niepodległość Ukrainy, stanowiąca historyczny akt zadośćuczynienia zgodny z linią Jerzego Giedroycia ${ }^{238}$. Od tego czasu projekcje programowe toru informacyjnego ulegały cyklicznym zawirowaniom pod wpływem kontekstów interpretacji sytuacyjnej na tle ideo-politycznym.

Mając na uwadze harmonizowanie programowych celów strategicznych i operacyjnych toru informacyjnego, zarówno polskiego i ukraińskiego, na początku lat 90. określono przestrzeń ramowa budowanego kontaktu między partnerami interakcji. Przyjęto otwarty model tego kontaktu (rapport), uznając że jego powodzenie zależeć będzie nie tylko z identyfikacji i interpretacji pozytywnych wartości/więzi, ale także $z$ naświetlania i niwelowania trudnych spraw, narosłych przez lata animozji, m.in. wskutek przemilczania „,białych plam” w historii stosunków polsko-ukraińskich. W 1992 r. podczas spotkania polsko-ukraińskiego (Kamieniec Podolski) uzgodniono kilka zasadniczych obszarów wspólnych działań toru informacyjnego, wyróżniając w pierwszej kolejności: (1) definiowanie wzajemnych stosunków kulturalnych i szans na wzmacnianie procesów odrodzenia narodowego; (2) rolę wyznaczników odpowiedzialnych za jakość kształtowania

\footnotetext{
${ }^{238}$ W podejściu Giedroycia, podobnie jak u Piłsudskiego czy gen. Charlesa de Gaulle ea, występowała idea roli narodów historycznych. Takim narodem z racji doświadczeń historycznych i miejsca cywilizacyjnego byli m.in. Polacy. Sama idea wywodzi się od George’a Hegla, głoszącego że prawdziwymi narodami są narody historyczne, a historyczne są tylko te, które rozwiązują zadania uniwersalne, przewyższające ich bezpośrednie interesy. Do stanowiska Hegla nawiązywała idea prometeizmu/neoprometeizmu i jego rola w desowietyzacji Europy Środkowo-Wschodniej. Współtwórca „Kultury” przestrzegał przed popełnieniem błędu Rzeczypospolitej Obojga Narodów wykluczającej Ukrainę z modelu federacyjnego (krótkowzroczna polityka polska pchnęła Ukrainę w stronę Rosji, ułatwiając jej formowanie pozycji imperialnej). Osią myślenia strategicznego Giedroycia było dążenie do zbudowania trwałego fundamentu polskiej polityki zagranicznej gwarantującej bezpieczne środowisko, zakotwiczone we wspólnocie zachodniej, w sojuszu z USA, a zarazem otwarte na pragmatyczne sąsiedztwo z Niemcami i integrację europejską. Gwarancją zewnętrznego środowiska bezpieczeństwa Polski stanowiło/stanowi przesuwanie się strefy stabilizacji na wschód strefy wraz $\mathrm{z}$ przejmowaniem zasad demokratyzacji życia publicznego. Tak powinno być i tak się stato - oceniał w $1991 \mathrm{r}$. ambasador Polski w Kijowie Jerzy Kozakiewicz w rozmowie z Bohdanem Osadczukiem, akcentując, że o efek $^{\text {tach }}$ zbliżenia zadecydują m.in. spójna polityka informacyjna i niwelowanie mentalnych uprzedzeń. $S q$ one głęboko zakodowane (podświadomie) w stosunkach polsko-ukraińskich). Musi miną́ sporo czasu, zanim powstanie nowa klasa polityczna, która będzie inaczej myślała i działała. ... Ukraina chcąc wejść do rodziny europejskiej, musi dostosować swój system do standardów demokratycznych. Rozmowa Bohdana Osadczuka z ambasadorem Polski w Ukrainie Jerzy Kozakiewiczem, „Kultura” nr 1-2, Paryż 1992, s. 118. W duchu nowego otwarcia filozofii polityki wschodniej Giedroycia wypowiadał się również Teodozjusz Starak (pierwszy ambasador Ukrainy w Warszawie): Polska ma dla nas szczególne znaczenie. Moim głównym zadaniem podkreślał będzie dązenie do usunięcia tych wszystkich nieporozumień $i$ nawarstwień, będacych rezultatem długoletniej komunistycznej propagandy, której głównym celem byto rozpalenie ognisk nienawiści pomiędzy naszymi narodami. Wypowiedź ambasadora Ukrainy w Warszawie Teodozjusza Staraka, „Kultura” nr 1-2, op. cit., s. 122.
} 
społeczeństwa obywatelskiego; (3) określenie zadań do podjęcia w ramach narodowych polityk historycznych, w tym przede wszystkim z udziałem mediów, a także przeglądu podręczników szkolnych z historii, geografii i literatury - w rozumieniu strategicznego wyzwania: Polska-Ukraina: spuścizna historyczna a społeczna świadomość". Mimo wyrażanego optymizmu towarzyszącemu poszukiwaniom pól budowania nowych interakcji nie ukrywano jednak obaw, zwłaszcza efektów zsynchronizowania ich całości na poziomie behawioralnym (mogącym się ujawniać w reakcjach motorycznych równoczesnych [inphase], identycznych [imitation], odzwierciedlonych [mirrored]) jak również lingwistycznym i mentalnym. Ta ostatnia kwestia wywoływała najwięcej wątpliwości m.in. na tle relacji międzykulturowych najbliższego środowiska zewnętrznego bezpieczeństwa państwa, spotęgowanego rozpadem Związku Radzieckiego i wyłonieniem się nowej sytuacji w relacjach sąsiedzkich na tzw. obszarze poradzieckim. Utrata Ukrainy (największa nierosyjska republika ZSRR z szóstą co do wielkości populacją w Europie - 50,1 mln) przez Rosję była dotkliwym ciosem wewnętrznym, jakie poniosło niedawne drugie supermocarstwo świata.

W modelu toru informacyjnego zakładano obecność trzech możliwych reakcji i zachowań wobec „starego-nowego obcego"239, licząc się z (1) możliwą kontestacją wiarygodności jednego $\mathrm{z}$ partnerów, (2) narastaniem rewindykacyjnych uprzedzeń historycznych ze strony środowisk nacjonalistycznych (polskich i ukraińskich) przywiązanych do kultywowanej symboliki, w tym emocjonalnej - martyrologicznej oraz (3) rozwijania pożądanego dialogu werbalnego i niewerbalnego, uznającego preferowane wartości, normy zachowania wraz z marginesem nieprzewidywalności zachowań w sytuacji istotnych różnić w ocenie wydarzeń.

Eksponowanie przewidywalności zachowań w przestrzeni publicznej z udziałem toru informacyjnego od początku pozostawało ważnym elementem równowagi przekazu, możliwego dzięki procesom socjalizacji i edukacji prowadzonej przez każdą ze stron interakcji. Było to jednak uproszczone widzenie potrzeb. W okresie prezydentury Leonida Krawczuka (1991-1994) i Leonida Kuczmy (1994-2005) obydwaj przywódcy wybrali „drogę środka” (parakontynuacja starego porządku),

\footnotetext{
${ }^{239}$ Socjokulturowa i etnokulturowa dychotomia swój-obcy jest strukturalnym elementem ukraińskiej przestrzeni publicznej, rodowodem sięgającym praktyki politycznej XIX-wiecznej ukraińskiej irredenty na terenie Galicji, aktywnie kształtującej świadomość etniczną Ukraińców. W głównej mierze odbywało się z udziałem kolportowanych programów stronnictw politycznych, demonstrujących gotowość realizowania celów geopolitycznych kosztem redukcji interesów „innych/obcych” grup. Konfrontacyjna atmosfera polityczna miała na celu wywoływanie napięć społecznych, potrzeby demonstrowania własnych wartości etnicznych i rewindykacyjnych.
} 
konserwującą miejsce Ukrainy w „eurazjatyckiej przestrzeni kulturalnej i gospodarczej” zdominowanej przez Rosję, poszukując ledwie ograniczonych więzi i inwestycji $z$ rozwiniętymi gospodarkami Europy Zachodniej, w niewielkim stopniu również z Polską.

Od początku nawiązania interakcji informacyjnej, każda ze stron wyrażała obawy wobec wrażliwości przeszłości historycznej, włączając sygnały ostrzegawcze opisujące mechanizmy obronne wobec różnic interpretacyjnych oraz podejmowanych zabiegów prewencyjnych. Naiwnie zakładano, co wydarzyło się już $w$ połowie lat 90., iż izolowanie ultraradykalizmu ukraińskiego doprowadzi do jego dekompozycji ideowej i marginalizacji w przestrzeni publicznej. Podobny symetryzm oceny sytuacji występował po polskiej stronie, gdzie w praktyce doszło do politycznej reaktywacji organizacji narodowych z rodowodem II Rzeczypospolitej: Młodzieży Wszechpolskiej, Obozu Narodowo-Radykalnego (ONR), Falangi-ONR oraz nowej, neofaszyzującej formacji „Szturmowcy”.

Po stronie ukraińskiej rewindykacyjny ruch nacjonalistyczny znalazł aktywne wsparcie wśród młodych Ukraińców (mówiących o sobie „oszukane pokolenie”). Terytorialnie ruch ten największy odzew znajdował wśród osób zamieszkałych głównie w zachodniej części kraju, demonstrujących postawy i zachowania wyrażające silny antypolonizm, antyrosyjskość, w tym roszczenia terytorialne pod adresem Polski. Przejawem skrajnie ultraradykalnych zachowań pozostawało i jest okazywanie uznania/sympatii wobec idei i symboli faszystowskich podczas publicznych manifestacji. Uwagę zwraca obecna w przestrzeni publicznej apologetyka restytucji państwa ukraińskiego pod przywództwem III Rzeszy, pochwały heroizmu batalionów Nachtigall i Rolnad - uosobienie siły, która wyzwoli kraj aryjski, kraj aryjski - Ukrainę ${ }^{240}$. Takie zachowania miał swój autonomiczny związek przyczynowo-skutkowy: pamięć w rodzinie, literatura dziewiętnastowieczna oraz lata 20. XX wieku, kult zakazanej symboliki odczytywanej na nowo w latach 90. Oficjalne koła rządowe reaktywację wzmożenia nacjonalistycznego usiłowały usprawiedliwiać skutkami kryzysów politycznych i gospodarczych na Ukrainie oraz poszukiwaniem własnej tożsamości, chociażby po raz pierwszy tak silnie zaznaczonym w czasie wydarzeń tzw. „pomarańczowej rewolucji” jesienią 2004 r., dekomponującej wysiłki Moskwy, mające na celu zwasalizować Ukrainę za pomocą środków politycznych.

W polskim torze informacyjnym źródła rewindykacji nastrojów nacjonalistycznych na Ukrainie wiązano z trudnym okresem przejściowym wyłaniania się Ukrainy po rozpadzie Związku Radzieckiego; nadawania kwestiom państwowotwórczym apriorycznej tożsamości,

${ }^{240}$ Nejaksinyj nacjonalizm, za: http:// www..pravda.com.ua (2020.11.09.) 
zawierającej wysublimowane i zukrainizowane wartości polityczno-kulturowe, etnicznoreligijne i wojskowe. Nie było tajemnicą, że ukraińskie organizacje radykalnonacjonalistyczne, programowo separujące się od tożsamości homo sevieticus, skupiły się na: (1) bezkrytycznym adaptowaniu elementów XIX-wiecznej i XX-wiecznej ultraradykalnej ukraińskiej myśli politycznej, ekonomicznej i wojskowej; (2) upowszechnianiu mitu Bandery w rozumieniu czynnika państwowotwórczego Ukrainy; (3) negowaniu obecności W ukraińskiej przestrzeni historycznej i kultury materialnej związanej z polskością; (4) wyłączeniu z głównego nutu życia publicznego każdego obcego/innego; (5) rozwijaniu współdziałania $\mathrm{z}$ zachodnioeuropejskimi organizacjami nacjonalistycznymi i neonazistowskimi, licząc na ich pomoc materialną, szkoleniowo-organizacyjną i informacyjno-wyjaśniającą ${ }^{241}$.

Wymienione obszary aktywności programowo-organizacyjnej podejmowane przez oficjalne koła rządowe sygnalizowały złożoność interakcji, wskazując, że dialog wymagać będzie żmudnego procesu kształtowania postaw otwartości i tolerancji z udziałem przede wszystkim wielopostaciowych oddziaływań edukacyjnych, informacyjnowyjaśniających i kulturalnych. Wiodącą rolę $\mathrm{w}$ tym zakresie posiadała strategia jednolitej polityki zagranicznej (w praktyce bardziej jej brak), uwzględniającej program przekonywania opinii publicznej, poprzez: (1) efekty relacji ekonomicznych (wsparcie finansowogospodarcze dostępność ruchu przygranicznego, polityka wizowa), otwartość w kontaktach na współpracę środowisk młodzieżowych, w tym tworzenie sprzyjających warunków podejmowania nauki i studiowania oraz możliwości podejmowania pracy; (2) przezwyciężanie utrzymujących się negatywnych stereotypów i mitów dotyczących innego/obcego, czyli delegitymizacji zjawiska potrójnej mityzacji i idealizacji ,ja - dobry”, inny/obcy ${ }^{242}$, co wiązało się $\mathrm{z}$ odchodzeniem przez każdą ze stron o nadwrażliwości idealizacji historycznej, czyli przypisywaniu pewnym wydarzeniom historycznym mocy trwania w teraźniejszości i przyszłości. Pamięta się najczęściej o pozytywnych aspektach przeszłości, wypierając $\mathrm{z}$ zbiorowej pamięci wydarzenia zakłócające wspaniały obraz własnego narodu. Polacy o sobie lubią mówić w kategoriach: romantyk, katolik, walczacy o wolność Wasza i nasza, nie zawsze rozumiejąc, że każda nadwymiarowa samoocena może

\footnotetext{
${ }^{241}$ Szkolenie w zakresu technik organizowania manifestacji publicznych: metodyka informowania o nich na portalach społecznościowych i telefonii komórkowej, naklejanie (na kilka godzin przed manifestacją) nalepek na szybach budynków i w komunikacji publicznej, tworzenie własnej subkultury zachowań (obowiązek zakrywania twarzy podczas manifestacji) i ubioru.

${ }^{242}$ B. Olszewska-Dyoniziak, Oblicza kultury. Wstęp do antropologii międzykulturowej komunikacji, Kraków 1998, s. 41.
} 
u interlokutora wywoływać negatywne emocje, umacniające negatywną stereotypizację innego/obcego. Takie zjawisko od początku towarzyszyło nawiązywaniu kontaktów międzykulturowych, w dużym stopniu negatywnie wpływając na postrzeganie uniwersalnego zespołu cech przypisywanych drugiej stronie.

Obie strony interakcji deklarowały gotowość konstruowania toru informacyjnego z uwzględnieniem zmiany podejścia do koncepcji relacji $\mathrm{z}$ odmiennością kulturową, polegającą na odchodzeniu od kulturocentryzmu i negatywnego wartościowania innych autonomicznych modeli kulturowych. Zakładano, że inny w tym modelu posiadać będzie status „osoby interesującej” - ciekawej/zainteresowanej poprzez swoją odmienność. Tym samym interakcje/spotkania $\mathrm{z}$ innym byłoby prymarne $\mathrm{w}$ poznawaniu i uznawaniu jego świata, jak i własnej kultury, otwierając przestrzeń dla stawania się przyjacielem. Jak było do przewidzenia taka koncepcja napotykała na wielorakie przeszkody, zwłaszcza natury programowej, realizacyjnej i mentalnej - po obu stronach. Problemem wymagającym wyzbycia się mentalnych, negatywnych stereotypów był krok w kierunku przyznania się, że inny także ma rację. W praktyce oznaczało to konieczność dokonania przeglądu obejmującego przewartościowania własnego zasobu kulturowego zakładającego zachowanie pewnych elementów, odrzucenie innych, przyjęcie nowych uwzgledniających istotne, suwerenne wartości, nade wszystko otwartość i tolerancja ${ }^{243}$.

Tempo wydarzeń wewnętrznych na Ukrainie od pierwszych lat XXI stulecia powodowało, że gros zadań toru informacyjnego poświęcony był identyfikacji i interpretacji wyznaczników granicznych „przełomów politycznych”: (1) „pomarańczowa rewolucja” w 2004 r.; prezydentura Wiktora Juszczenki (2005-2010), w okresie której Moskwa użyła narzędzi wojny ekonomicznej w celu przywrócenia kontroli nad ukraińską infrastrukturą energetyczną (zwłaszcza jej ważnym systemem transportu gazu ziemnego do Europy Zachodniej); (2) umocnienie się ukraińskich grup oligarchicznych sponsorów życia finansowo-gospodarczego ( $\mathrm{w}$ większości powiązanych z rosyjskimi kołami oligarchicznymi i służbami specjalnymi); (3) dekompozycja koalicji „pomarańczowej rewolucji” i jej implikacje skutkujące m.in. powrotem do władzy prezydenta Wiktora Janukowycza (20102014), doprowadzając do oddzielenia Ukrainy od liberalnych demokracji i opartych na regułach rynku gospodarek Zachodu, sytuując natomiast kraj po stronie autorytarnych i kontrolowanych przez oligarchów reżimach Wschodu (odrzucenie oferty Unii Europejskiej, słabość unijnej strategii Partnerstwa Wschodniego) wraz z pozostaniem w „,bliskiej

${ }^{243}$ Ibidem, s. 33. 
zagranicy" gwarantującej uprzywilejowane interesy z Moskwą; (4) kwestie kulturowe, historyczne i geopolityczne - podkreślające, że Ukraina jest częścią Europy, tym samym ma prawo do istnienia w Europie w znaczeniu politycznym, a także do gwarantowanego przez Europę bezpieczeństwa.

Analiza toru informacyjnego wskazuje, że także dla strony polskiej geopolityczny problem Ukrainy pozostawał dwojaki. Z jednej strony dochodziło do przeceniania politycznego i ekonomicznego kapitału, w tym zdolności inwestycyjnych, aby postawić ten kraj na solidnych fundamentach rozwojowych, z drugiej strony nie zdawano sobie sprawy, że kontrola nad Ukrainą była dla Rosji sprawą pierwszoplanową w utrzymaniu gwarancji jej bezpieczeństwa. Ignorowanie tego faktu zapowiadało fatalny błąd o wielorakich konsekwencjach. Nie doceniano również, że każde inicjatywy Zachodu służące „wybiciu” Ukrainy z rosyjskiej strefy wpływów i strefy interesów ${ }^{244}$ - bez specjalnych, dużych nakładów finansowych będą kończyć się fiaskiem. Wątpliwej jakości okazały się również wnioski z analiz NATO na temat kondycji rosyjskich sił zbrojnych, sugerujące zgrzybiaty cień dawnej świetności, uświadamiających światu w świetle inkorporacji Krymu (2014) i rosyjskiej interwencji w Syrii (2015), jak szybko Rosja odbudowuje swoją pozycję wojskową w regionie (przekształcenie Krymu w silnie ufortyfikowany południowy bastion, zapewniający przekształcenie Morza Czarnego w de facto w wewnętrzny akwen Rosji, Obwód Kaliningradzki - przyczółek mający uniemożliwić NATO dostęp do Morza Bałtyckiego) ${ }^{245}$. Działania Zachodu (sankcje polityczne i gospodarcze) w reakcji na inkorporację Krymu i rozwój sytuacji w separatystycznych obwodach we wschodniej Ukrainie - zamiast powstrzymać dalszą agresję spowodowały przekształcenie Rosji z potencjalnego partnera w otwartego przeciwnika, służąc umacnianiu reżimu Putina ${ }^{246}$.

\section{Konkluzje}

Pomimo wojny i pogmatwanej polityki, Ukraina kontynuuje politykę stania się państwem narodowym. Utrata Krymu i sytuacja w separatystycznych częściach

\footnotetext{
${ }^{244}$ Podobnie jak w okresie stalinowskim, rosyjski imperializm doby Putina niezmiennie wspiera utrzymanie Ukrainy w orbicie oddziaływań Moskwy, wykorzystując przestrzeń ukraińską jako platformę do ewentualnych operacji podejmowanych wobec Polski (m.in. wojna hybrydowa) a także innych krajów Europy. Moskwa swoje roszczenia uzasadniania względami historycznymi o wspólnym języku i kulturą oraz zaprzeczaniem, jakoby Ukraina miała prawo do niezależnej państwowości.

${ }^{245}$ S. Hedlund, Krymski bastion, Geopolitical Intelligence Servis 2016, s. 1-2.

${ }^{246}$ Nie obyło się do strat, konflikt z Ukrainą nadwyrężył idee Eurazjatyckiej Unii Gospodarczej, która wydawała się realną alternatywą pokojowego wspótistnienia państw do marca 2014 r. oraz wzbudził obawy innych państw obszaru poradzieckiego, takich jak Azerbejdżan, Kazachstan i kraje Azji Środkowej, które zaczęły zwracać się w stronę Chin.
} 
b. obwodów donieckiego i ługańskiego spowodowała spolaryzowanie ukraińskojęzycznej ludności, skutkując także podsycaniu nastrojów narodowych Ukraińców, wzmacnianiu emocjonalnych więzi i poświęcenia się na rzecz niezależnego państwa.

Inkorporacja Krymu i wojna na wschodzie przyspieszały reformy w państwie, w tym armii ukraińskiej, czyniąc z niej siłę szybko modernizującą się co podwójne znaczenie - społeczne: element doboru nowych kadr oddanych ideałom przemian ustrojowych, polityczne: tworzenie przesłanek do umacniania strefy demokracji w Europie Wschodniej.

W styczniu 2017 r. w momencie rozpoczęcia prezydentury Donalda Trumpa zakładano, że nowa administracja może okazać się skuteczniejsza od poprzedniej, Baracka Obamy i starać się będzie dostrzegać kwestię ukraińską. W ślad za deklaracjami o negatywnej roli Rosji na Ukrainie i w Donbasie pojawiły decyzje o nowych, amerykańskich sankcjach przeciw rosyjskim interesom gospodarczym oraz zapowiedzi w sprawie zezwolenia Senatu USA w sprawie dostarczenie Ukrainie pomocy wojskowej, w tym „śmiercionośnej broni defensywnej" (mowa była o ręcznej wyrzutni pocisków przeciwpancernych PGM-148 Javelin).

Sytuacja na Ukrainie od lutego 2014 r. wskazuje konfrontację z jednej strony o cechach wojny zastępczej a z drugiej konfliktu zamrożonego, w której nie dopuszcza się czarnego scenariusza „oddania Ukrainy Rosji”, ale nadzieje Zachodu na jego rozwiązanie w trybie negocjacyjnym, np. „format normandzki” czy też, że Rosja nie wytrzyma narastających politycznych kosztów okupacji - pozostawać będą myśleniem życzeniowym. Moskwa jest w stanie uruchomić lokalne formy eskalacji napięć etniczno-terytorialnych na obszarze poradzieckim oraz i decydować o ich przebiegu i trybie zakończenia (przykład wojna ormiańsko-azerska w Górskim Karabachu - jesień 2020 r., studząca prozachodnie nowej ekipy rządzącej w Armenii). Celem strategicznym Kremla jest utrzymanie przyczółka we wschodniej Ukrainie, co pozwala mu zawetować jakikolwiek ruch Kijowa w stronę zbliżenia ze strukturami euroatlantyckimi.

Słabością przekonywania opinii ukraińskiej z udziałem toru informacyjnego jest format rozwiązywania konfliktu obrany przez Unię Europejską. Jak pokazuje praktyka jego format przygotował mimowolnie grunt pod trwałe jego zamrożenie, $\mathrm{z}$ wszystkimi tego stanu implikacjami mającymi wpływ na przyszłość relacji UE-Rosja a także USA-Rosja. Dla Ukrainy takie rozwiązanie pozostaje wysoce niekorzystne. 


\section{Streszczenie:}

Przedmiot badań powiązany jest $\mathrm{z}$ formowaniem i rolą socjostruktury systemu społecznego Polski, jej zdolności identyfikujących i interpretujących zmiany postrzegania jakości zewnętrznego środowiska bezpieczeństwa w kontekście „trudnej przyjaźni” Polski i Ukrainy. Zasadniczym wyzwaniem i zagrożeniem dla tej zmiany stanowił/stanowi „tor informacyjny” w kontekście stabilności sterowania w rozumieniu cybernetyki społecznej. Zasadnicze pole badawcze dotyczy wpływu socjostruktury na perspektywy interpretacji „trudnej przyjaźni” z udziałem informacji. W tym celu przyjęto, iż metody socjocybernetyczne posiadają właściwą moc diagnostyczną w badaniu trendów opiniotwórczych struktur społecznych i toru informacyjnego, funkcjonujących jako systemy sub-autonomiczne. Warto podkreślić, że wskazane stanowisko pozwala także na wyeksplikowanie pierwotnych przyczyn (wystarczających i niezbędnych) systemu bezpieczeństwa (konceptualizacja) z udziałem toru informacyjnego.

\section{Słowa kluczowe:}

bezpieczeństwo systemów społecznych, cybernetyka społeczna, tor informacyjny, trudna przyjaźń

\section{Key words:}

security of social systems, social cybernetics, information track, difficult friendship

\section{Bibliografia:}

1. Jagusiak B., Bezpieczeństwo społeczne, Difin, Warszawa 2014.

2. Jaźwiński J. Ważyńska-Fiok K., Bezpieczeństwo systemów, Warszawa 1993.

3. Kossecki J. , Cybernetyka społeczna, PWN, Warszawa 1981.

4. Kossecki J., Elementy nowoczesnej wiedzy o sterowaniu ludźmi, WZiA, Kielce 2001.

5. Kossecki J., Metacybernetyka, NAI, Warszawa 2015.

6. Kubiaka M. (red.), Jaczyński S. (red.), Minkina M. (red.), Współczesne bezpieczeństwo polityczne, UPH, Warszawa-Siedlce 2012.

7. Marcinkowski M. (red.), Zuber M. (red.), Edukacja dla bezpieczeństwa $w$ społecznościach lokalnych, Wyd. Wyższej Szkoły Humanistycznej im. Stanisława Leszczyńskiego w Lesznie, Leszno 2013.

8. Monteskiusz K, O duchu praw, Wyd. Hachette, Warszawa 2009.

9. Rocznik statystyczny RP 1986-2018, GUS, Warszawa 1986-2018.

10. Rosa R., Bezpieczeństwo i edukacja dla bezpieczeństwa w zmieniającej się przestrzeni społecznej i kulturowej, UPH , 2012.

11. Rousseau J. J., Umowa społeczna. List o widowiskach, przeł. Antoni Peretiatkowicz, Wyd. PWN, Warszawa 2010.

12. Świniarski J. , O naturze bezpieczeństwa, ULMAK, Warszawa-Pruszków 1997.

13. Świniarski J., Chojnacki W., Filozofia bezpieczeństwa. Podręcznik Akademicki, Warszawa 2004.

14. Świniarski J., Kawalerski P., Drogi i bezdroża securitologii, Warszawa 2019. 
15. Świniarski J., Źródła realistycznej i idealistycznej tradycji refleksji o bezpieczeństwie narodowym, „Studia Bezpieczeństwa Narodowego” (7) 2011.

16. Wójcik K., Sposób na cięcia w administracji, „Rzeczpospolita” nr 234 (9658)/2013. 